\title{
APLIKASI METODE TOTAL QUALITY MANAGEMENT LEMBAGA PENDIDIKAN DALAM PRESPEKTIF EPISTIMOLOGI ISLAM
}

\author{
Oleh \\ Hasyisyatun Nurun Nisa' \\ Universitas Nurul Jadid \\ syasyaadmirable@gmail.com
}

\begin{abstract}
Abstrak
Dalam suatu lembaga pendidikan TQM sangat diperlukan, karena melihat dari sisi globalisasi sekarang banyak lembaga yang berlomba-lomba untuk meningkatkan kualitas masing-masing lembaga agar dapat di lihat masyarakat sekitar. Oleh karena itu, TQM tidak hanya untuk memanej sebuah lembaga saja tapi juga digunakan untuk mamenej perusahaan. Dapat kita ketahui makna Manajemen Mutu Terpadu adalah suatu sistem yang berhubungan dengan karyawan pada perusahaan yang bertujuan untuk memajukan kualitas pada organiasi tersebut untuk lebih baik kedepannya. Dalam pendidikan islam epistimologi selama ini masih didominasi corak klasik yang kurang memberikan penghargaan terhadap perkembangan yang kompleks. Selain itu, epistimologi barat yang bercorak positivis-empiris-logis menjadikan corak yang bernuansa khas dalam pendidikan islam harus "berkompetisi" dengan corak barat. Pada titik inilah, penguatan epistimologi dengan menentukan titik temunya dapat membangun landasan keilmuan dan pengembangan secara lebih terperinci. Jadi MTQM dalam epistimologi islam ini adalah proses mengembangkan ilmu pengetahuan dengan menggunakan arah pikir manusia.
\end{abstract}

\section{Pendahuluan}

Pendidikan merupakan lembaga yang dapat membantu menigkatkan kualitas warga bangsa, sehingga banyak lembaga yang berlomba-lomba untuk meningkatkan kualitas lembaga mereka agar menjadi lebih baik. Dimana, perbaikan pendidikan sangat dituntut di era informasi dan era globalisasi saat ini. maka semua pihak yang berada dalam proses 
akademis, seperti strukturalisasi di sekolah harus mengerti bagaimana dasar dan tujuan pendidikan dalam sekolah tersebut.

Dalam ajaran TQM, dijelaskan bahwa sebuah sekolah harus menjadikan siswa sebagai "pelanggan" atau "stakeholders", sehingga pendapat siswa dapat membantu dalam mengambil langkah yang lebih strategis pada organisasi sekolah. Karena, itu merupakan sebuah proses yang bisa digunakan untuk melakuakan perbaikan lembaga pendidikan dan lain-lain. Sehingga kebebasan berpendapat dapat membantu interaksi antara siswa dengan karyawan dan mutu sekolah. Mutu tidak akan terjadi secara tiba-tiba, tapi mutu itu akan ada jika direncanakan. Sehingga kata mutu dapat kita artikan juga dengan Basic, Value, Caracteristic yang mana mutu ini sangat dibutuhkan dalam sebuah institusi atau yang lain.

Dalam hal ini masih banyak lembaga-lembaga yang menginginkan lembaga bagus tapi tidak mengetahui bagaimana cara memenejemen lembaga mereka dengan baik. Sehingga dalam pembahasan ini penulis akan menjelaskan bagaimana menggunakan MTQM (Metode Total Quality Manajemen) dalam lembaga pendidikan.

\section{Makna Metode Manajemen Mutu Terpadu (MTQM) dan Epistimologi}

TQM adalah sebuah pendekatan yang digunakan untuk mencapai tujuan bersama dengan cara memotivasi anggota agar bersedia untuk gotong royong dalam budaya organisasi.

MTQM adalah sebuah cara atau pola untuk mencapai sebuah komitmen dalam organisasi, sehingga dapat merubah atau mencapai tujuan dengan baik. Sedangkan TQM menurut pandangan islam adalah suatu sitem manajemen yang dapat meningkatkan kualitas untuk menuju pencapaian yang lebih unggul dengan memberikan kepuasan kepada pelanggan yang di dasarkan pada Al-qur'an dan As-sunnah. Oleh karena itu dengan penerapan ini dapat memberikan profit bagi perusahaan dan pelanggan dengan cara yang dibenarkan oleh islam.

Ada beberapa penemu yang memaparkan tentang MTQM salah satunya adalah W. Edwards Deming. Metode deming ini merupakan salah satu metode yang dikenal dengan siklus deming (deming cycle). Siklus deming ini merupakan model perbaikan terus menerus yang terdiri dari empat susunan utama secara berurutan, model ini di sebut siklus PDCA (Plan-Do-Check-Act). Pengertian dari siklus PDCA yaitu: 
1. Plan (Mengembangkan Rencana Perbaikan)

Plan merupakan langkah awal untuk perbaikan rencana yang disusun dengan menggunakan 5-W dan 1-H dan memerhatikan prinsip SMART (Specific/Tertentu, Measurable/Terukur, Attainable/Dapat dicapai, Reasonable/Masuk akal, Time/Waktu)

\section{Do (Melaksanakan Rencana)}

Do merupakan langkah kedua setelah plan yang telah diimplementasikan, mulai dari sebuah hal yang terkecil. Dalam melaksanakan sebuah rencana harus dilakukan dengan pengendalian, agar rencana dapat berjalan sesuai sasaran yang ingin dicapai.

3. Check (Memeriksa atau Meneliti sesuatu yang dicapai)

Check merupakan langkah ketiga setelah do yaitu memeriksa atau meneliti progress perbaikan yang telah direncanakan.

\section{Action (Melakukan Tindakan Penyesuaian)}

Action merupakan penyesuaian yang berkaitan dengan ukuran dasar prosedur guna untuk menghindari masalah yang sama.

Epistimologi adalah salah satu ilmu filsafat yang menentukan arah suatu pengetahuan atau berurusan dengan hakikat pengetahuan. Terkadang epistimologi bisa dijadikan penyaring terhadap objek-objek pengetahuan, oleh karena itu, tidak semua objek pengetahuan harus dijelajahi. ${ }^{1}$ Dalam pendidikan islam epistimologi selama ini masih didominasi corak klasik, dimana corak klasik ini kurang memberikan nilai atau penghargaan terhadap perkembangan yang kompleks. Selain itu, epistimologi barat yang bercorak positivis-empiris-logis menjadikan corak yang bernuansa khas dalam pendidikan islam harus berlomba-lomba dengan corak barat.

Pada titik inilah, penguatan epistimologi dengan menentukan titik temunya dapat membangun landasan keilmuan dan pengembangan de lebingan terperinci. Jadi MTQM

${ }^{1}$ Mujamil Qomar, Epistimologi Pendidikan Islam, dari Metode Rasional hingga Metode Kritik, Jakarta: Erlangga, 2006 
dalam epistimologi islam ini yaiyu sebuah pendekatan yang menggunakan arah pikir manusia untuk mengembangkan pengetahuan.

\section{Tujuan TQM}

TQM adalah sebuah sistem manajemen yang bertujuan untuk mengembangkan produktifitas lembaga dengan menggunakan metode-metode yang mendukung. Atau dapat kita maknai juga dengan sistem yang mengembangkan produk atau jasa di lembaga agar dapat menimbulkan kepuasan konsumen atau semua pihak.

\section{Aplikasi MTQM Lembaga Pendidikan}

Dasar dari TQM dalam dunia pendidikan menurut Frankin P. Schargel (1994:2) dikatakan bahwa mutu pendidikan dapat dipahami seagai suatu proses yang ikut serta pada pencapaian kepuasan pelanggan pendidikan. ${ }^{2}$

Dalam suatu pendidikan akan membutuhkan suatu proses yang dapat mengembangkan. Seperti halnya dalam proses belajar mengajar akan melibatkan beberapa komponen yaitu: ${ }^{3}$

1. Peserta pembelajar

2. Guru

3. Tujuan pembelajaran

4. Isi pelajaran

5. Metode

6. Media belajar

7. Evaluasi

\footnotetext{
${ }^{2}$ Syafaruddin, 2002, Manajemen Mutu Terpadu dalam Pendidikan, Jakarta: PT. Grasindo.

${ }^{3}$ Sania Vand Sisk, dkk. Metode Pembelajaran dalam Pendidikan dan Pelatihan, makalah 2016
} 
Dari ketuju itu ada salah satu yang benar-benar berpengaruh kepada perkembangan pendidikan yaitu metode. Karena metode atau model pendekatan ini memiliki banyak fariasi, maka kita harus bisa menggunakan metode-metode yang tepat dalam penggunaan, agar tidak terjadi kesalahan.

Model TQM terdiri dari 2 pendekatan yang dapat kita gunakan yaitu:

1. Traditional Management Approach (Model Pendekatan Tradisional) adalah model yang banyak digunakan, seperti pemimpin membuat sebuah pendekatan TQM dengan menggunakan penerapan TQM yang akan diberikan atau dijalankan kepada anggota atau pekerja yang lain. Hal ini berarti bahwa pemimpin tidak bekerja sama dengan para anggota dalam membuat TQM itu sendiri. Sehingga $80 \%$ pendekatan ini mengakibatkan kegagalan. Ini terjadi karena kesan antara TQM dan pendekatan ini menimbulkan cara yag tidak sehat atau usaha yang berhenti tiba-tiba ketika seorang pekerja merasa tidak mampu atau sudah puas.

2. Integrated Management Approach (Model Pendekatan Terpadu)TQM adalah penggabungan dan persamaan antara budaya kerja staf dengan budaya yang diciptakan TQM, sehingga pendekatan ini menghubungkan semua kebutuhan serta kebudayaan staf dengan alur dan tujuan yang ada pada TQM. Dengan begitu, di antara semuanya akan menghasilkan sebuah integritas, kesepahaman, tanpa ada rasa saling merugikan dan mereka akan menjadi lebih baik dengan tanpa merasakan suasana perlombaan yang tidak sehat seperti Rat Race dan Runs end. Tingkat keberhasilan ini sangat tinggi karen sesuai dengan tingkat keberhasilan yang di inginkan perusahaan dengan kemampuan dan kemauan para pelaksana.

Untuk memperoleh mutu yang diinginkan, tentu membutuhkan perencanaan yang matang, karena untuk mengejar mutu, maka kesalahan harus diperbaiki untuk mencapai kenggulan yang sesuai dengan tujuan.

Menurut Joseh C. Field, bahwa ada beberapa langkah untuk menerapkan MTQM

1. Mempelajari dan memahami MTQM secara menyeluruh.

2. Memahami dan meningkatkan jiwa untuk perbaikan yang terus menerus.

3. Membangun sistem kualitas terpadu. 
4. Mempersiapkan dan menilai budaya mutusebagai tujuan untuk mempersiapkan perbaikan.

5. Mempelajari teknik untuk menyerang atau mengatasi penyebab suatu masalah.

6. Menetapkan prosedur tindakan perbaikan.

Dari langkah-langkah diatas, yang harus ditempuh untuk mencapai TQM harus memenuhi beberapa syarat, sebagai berikut:

1. Peningkatan secara berkesinambungan

Digunakan suatu pendekatan TQM untuk mencari sebuah bentuk yang tetap dalam lembaga, sehingga tidak diarahkan pada jangka pendek, melainkan diarahkan pada peningkatan kualitas jangka panjang.

2. Perubahan budaya

Dalam melaksanakan budaya yang harus dilakukan adalah "melelehkan" kemudian menggerakan ke arah yang lebih baru, dan jika sudah sesuai atau tepat maka digunakan lagi.

3. Komunikasi

Komunikasi dapat menciptakan budaya kualitas yang diharapkan, sehingga seuruh jaringan dan media komunikasi baik secara vertikal dan horizontal perlu dioptimalkan.

4. Menjaga hubungan

Pemimpin lembaga pendidikan harus lebih mengutamakan konsumen. Karena menjaga hubungan itu penting dan dilandaskan pada ciri utama penentu kualitas adalah pelanggan yang akhirnya menentukan kualitas. Profesional itu juga diperlukan untuk memenuhi Keseimbangan dalam semua pelanggan baik internal maupun eksternal. 


\section{Kesimpulan}

Manajemen merupakan sebuah proses untuk memperbaiki kehidupan umat manusia. Sehingga lembaga pendidikan juga menggunakan manajemen dalam memperbaiki mutu pendidikan, meski perlu meningkatkan inovasi-inovasi manajemen dalam upaya meningkatkan kualitas mutu yang baik. Mutu Pendidikan adalah sebuah pendekatan yang melalui peningkatan mutu komponen. Menurut filsafat meningkatkan mutu itu harus dilaksanakan sejak dini dengan berterus-terusan oleh semua lembaga, sehingga dengan adanya mutu yan bagus pendidikan akan dijadikan sebagai jasa pembudayaan yang sesuai dan bahkan dapat mengungguli kebutuhan para pelanggan, baik sekarang atau masa yang akan datang. Dalam TQM itu juga ada metode yang mana, metode itu dapat membantu proses peningkatan mutu dalam pendidikan. Dua pendekatan Model TQM yang dapat kita gunakan 1. Traditional Management Approach (Model Pendekatan Tradisional) 2. Integrated Management Approach (Model Pendekatan Terpadu). Sehingga dalam melaksanakan

peningkatan kualitas mutu pendidikan perlu dilaksanakan metode yang disebut dengan metode PDCA (Plan-Do-Chek-Act). Dimana metode ini divisualikan oleh Deming.

\section{Daftar Pustaka}

B. Creech.Lima pilar (Manajemen Mutu Terpadu) TQM: Cara membuat Total Quality Management Bekerja bagi anda, Alih bahasa: Sindoro. A.1996.Jakarta:Binarupa Aksara

B. Ibrahim.TQM: Panduan untuk menghadapi persaingan global.2000 Jakarta:Djambatan

Field, Joseph C.Total Quality Management. 1993.Wisconsin:ASQC Quality Press

Franklin P. Schargel.Transforming Education Through Total Quallity Management: A Practitioner"s Guide. 1994.New York:EYE on Education

Gaspersz, Vincent.Total Quality Management.2005.Jakarta:PT. Gramedia Pustaka Utama

Hardjosoedarmo, Soewarso. Total Quality Management. 1996.Yogjakarta:Andi Offset

J. Hradesky.Total Quality Management. 1995.New York:McGraw-Hill, Inc 
Sallis, Edward.Total Quality Management in Education, London, Kogan Page Educational Management Series.1993

Soedarmo, Harjo.Dasar-dasar Total Quality Management.1997. Yogyakarta:Andi

Tjiptono, dkk. Total Quality Manajemen.2003.Yogyakarta:Andi

Syafaruddin.Manajemen Mutu Terpadu dalam Pendidikan.2002.Jakarta: PT. Grasindo.

Sania Vand Sisk, dkk. Metode Pembelajaran dalam Pendidikan dan Pelatihan, makalah 2016

Mujamil Qomar.Epistimologi Pendidikan Islam, dari Metode Rasional hingga Metode Kritik. 2006. Jakarta: Erlangga,

Mundiri, A. (2015). KOMITMEN ORGANISASIONAL SUMBER DAYA MANUSIA DALAM MENINGKATKAN MUTU PENDIDIKAN PESANTREN. Pedagogik, 3(1), 88-105.

Mundiri, A. (2016). THE LEADERSHIP OF HEADMASTER IN BUILDING A WORK CULTURE BASED ON PESANTREN. In International Conference on Education and Training (pp. 1-7). Malang: Faculty of Education State University of Malang. 